\title{
THE PERMIAN AND TRIASSIC OF THE CAPE STOSCH AREA, EAST GREENLAND
}

Tove Birkelund

In 1967 a cooperative study of the Permian and Triassic of the Cape Stosch area was carried out by an American-Swiss team (Professor C.Teichert, Kansas; Professor B.Kummel, Harvard; Professor R. Trümpy, Zurich) and a Danish team (Professor T. Birkelund, Dr Eigil Nielsen, Mag. scient. S. Bendix-Almgreen, and stud. scient. Lone Malmros).

The marine Upper Permian deposits as they are developed along the north coast of Hold with Hope in the Cape Stosch area comprise the following members: (a) A thick basal conglomerate (about $145 \mathrm{~m}$ thick at river 15), (b) dolomite beds, (c) grey, unfossiliferous dolomitic limestone containing gypsiferous zones, (d) black bituminous shales (Posidonomya Shales) containing in their upper part one to three limestone bands (the fish zones) and (e) greygreenish limestone beds (Martinia Limestone) containing grey marl zones and a layer of highly fossiliferous limestone (brachiopod limestone) (Nielsen, 1935; Maync 1942).

The Triassic deposits, 500-700 $\mathrm{m}$ thick, conformably or paraconformably overly the Martinia Limestone and are unconformably overlain by Lower Cretaceous sandstones and by Tertiary plateau basalts. The deposits has been described by, amongst others, Rosenkrantz (1930), Koch (1931), Nielsen (1935) and Trümpy (1960).

The lower part of the Triassic consists of highly variable deposits mainly of near-shore origin: loose or compact sandstones, siltstones and shales with calcareous concretions and calcareous bands. Certain horizons of this part of the Triassic are very fossiliferous, containing rich ammonite and fish faunas.

Spath $(1930,1935)$ referred this ammonite-bearing part of the Triassic to the Lower Scythian and divided the deposits into (a) the 
Glyptophiceras beds, (b) the Ophiceras beds, (c) the Vishnuites beds, and (d) the Proptychites beds. These deposits are among the world's most completely developed and most fossiliferous Lower Scythian deposits.

The upper part of the Triassic section, (e) the Anodontophora breviformis beds and ( $f$ ) the Anodontophora fassaensis beds, consists of sandstones and variegated shales. Except for a few shell beds with pelecypods and gastropods and a horizon containing stegocephalians, this part of the Triassic is nearly unfossiliferous. No ammonites have been found in these beds.

The Triassic contains seven prominent conglomeratic horizons in the western part of the area. To the east the conglomerates gradually disappear or grade into massive sandstone horizons. The pebbles of the conglomerates are derived from the west or northwest. The lower conglomerates contain fossiliferous Permian pebbles (the so-called "white blocks").

Professor C. Teichert and Professor B. Kummel investigated first and foremost the Permian-Triassic boundary layers, particularly the Triassic Glyptophiceras beds. These beds are of great significance because here is one of the few places in the world where Permian and Triassic faunas occur together.

Unfortunately, detailed observations of the contact between the Permian and Triassic formations were hindered in most places by solifluction.

Six stratigraphic sections were studied and measured in detail in river valleys between River 0 and River 14. In each of these sections extensive sampling was carried out. Many of the samples were collected specifically for microfossils. A number of specialists have already agreed to study these samples. In addition lithological samples were collected from every measured unit for petrographical study.

The extensive sampling programme will enable an intensive study of the macro- and micro-fossils plus the lithological character of the rocks from both sides of this important geological boundary. 
Professor R. Trümpy mapped the area between River 7 and Extraelv, an area complicated by faults, landslides and solifluction.

Tove Birkelund and Lone Malmros investigated mainly the ammonite-bearing Lower Scythian deposits, especially the Ophiceras beds, the Vishnuites beds, and the Proptychites beds. They studied and measured 12 sections between River 6 and River 16 plus two sections on the Stensiö Plateau. The main purpose of this work was to obtain new stratigraphically well determined ammonite collections from sections where solifluction was minimal.

From these Ophiceras, Vishnuites, and Proptychites beds Spath $(1930,1935)$ has described 44 species belonging to 12 different genera and subgenera and referred to 6 ammonite zones. The new collections provide a basis for evaluating Spath's species concept and the stratigraphical occurrence of some of the species.

The collecting of Triassic fishes was the aim of Dr Eigil Nielsen, who has previously secured large vertebrate and ammonite collections from the Triassic beds. Dr Nielsen is continuing his description of the Triassic fish fauna (Nielsen, 1936, 1942, 1949). The new collections include coelacanthids, paleoniscoids, and ichthyodorulites. A single fragment of a stegocephalian was also secured.

Fossil collecting from the Permian beds was the task of Svend E. Bendix-Almgreen, who is deeply involved in the investigation of the elasmobranch fauna from these deposits. The work was concentrated mainly on the fish zones in the Posidonomya shales, which previously have yielded a large number of vertebrates (edestids, cladodontids, ? ctenacanthids, petalodontids, ichthyodorulites, paleoniscoids; Nielsen, 1932, 1935, 1952; Aldinger, 1937; Stensiö, 1961; BendixAlmgreen, 1961, 1967). The new collections contain further material of edestids (neurocrania, pectoral fins, ?pelvic fins, caudal fins and ?anal fins), petalodontids (including a large part of a single individual, not yet determined), part of a scale-covering of an undetermined but probably new elasmobranch and further finds of paleoniscoids. Various invertebrates were also collected, including new finds of belemnoids. 


\section{References}

Aldinger, H. (1937) Permische Ganoidfische aus Ostgrönland. Medd. Gr $\phi$ nland, Bd. 102, Nr. 3.

Bendix-Almgreen, S. E. (1962) De $\phi$ stgr $\phi$ nlandske perm-edestiders anatomi, med særligt henblik på Fadenia crenulata. Medd. dansk geol. Foren., Bd. 15, Nr. 1, 152-153.

Bendix-Almgreen, S.E. (1967) On the fin-structure of the Upper Permian Edestids from East Greenland. Medd. dansk geol. Foren., Bd. 17, Nr. 1, 147-149.

Koch, L. (1931) Carboniferous and Triassic Stratigraphy of East Greenland. Medd. Gronland, Bd. 83, Nr. 2.

Maync, W. (1942) Stratigraphie and Faziesverhältnisse der OberPermischen Ablagerungen Ostgrönlands. Medd. Grønland, Bd. 115, Nr。2.

Nielsen, E. (1932) Permo-Carboniferous fishes from East Greenland. Medd. Grфnland, Bd. 86, Nr. 3.

Nielsen, E. (1935) The Permian and Eotriassic vertebrate-bearing beds at Godthaab Gulf (East Greenland). Medd. Grфnland, Bd. 98, Nr. 1.

Nielsen, E. (1936) Some few preliminary remarks on Triassic fishes from East Greenland. Medd. Grфnland, Bd. 112, Nr. 3.

Nielsen, E. (1942) Studies on the Triassic fishes from East Greenland. I. Glaucolepis \& Boreosomus. Medd. Grønland, Bd. 138.

Nielsen, E. (1949 Studies on the Triassic fishes from East Greenland. II. Australosomus \& Birgeria. Medd. Grфnland, Bd.146, Nr. 1 .

Nielsen, E. (1952) On new or little known Edestidae from the Permian and Triassic of East Greenland. Medd. Grфnland, Bd. 144, Nr. 5.

Rosenkrantz, A. (1930) Summary of investigations of younger Palæozoic and Mesozoic strata along the east coast of Greenland in 1929. Medd. Grфnland, Bd. 74, Nr. 14, 347-364.

Spath, L. F. (1930) The Eotriassic invertebrate fauna of East Greenland. Medd. Grønland, Bd. 83, Nr. 1. 
Spath, L.F. (1935) Additions to the Eo-Triassic invertebrate fauna of East Greenland. Medd. Grфnland, Bd. 98, Nr. 2.

Stensio, E. (1961) Permian vertebrates. In Raasch, G.H. (edit.) Geology of the Arctic, Vol. 1, 231-247. Univ. of Toronto Press.

Trumpy, R. (1961) Triassic of East Greenland. In Raasch, G. H. (edit.) Geology of the Arctic, Vol. 1, 249-254. Univ. of Toronto Press.

K/Ar AGE DETERMINATIONS FROM WESTERN GREENLAND I. RECONNAISSANCE PROGRAMME

Ole Larsen and J $\phi$ rgen M $\phi$ ller

A reconnaissance $\mathrm{K} / \mathrm{Ar}$ dating programme on rocks from western Greenland has been carried out with an Ar-extraction apparatus set up at Fysisk Laboratorium II, H. C. $\emptyset$ rsted Institut. The mass spectrometric Ar determinations were carried out in the same laboratory by the second author. With the completion of this reconnaissance programme the extraction apparatus was moved to the Mineralogical-Geological Institute of the University of Copenhagen. Major changes are being made in connection with the re-establishment of the dating laboratory, and dating will not be resumed before the spring of 1968 .

The preliminary results of the reconnaissance programme were presented in the Report of Activities, 1966. These results have now been checked and given values of standard error, and the figures reported earlier must be considered obselete. The corrected figures are presented in the tables on the following pages, together with five determinations not included in last year's report. Details concerning these five determinations are given below. 